DOI 10.15393/j9.art.2018.5441

УДК 821.161.1.09“18”

Елена Юрьевна Сафронова

(Барнаул, Российская Федеращия)

esafr@mail.ru

\title{
Genius loci в поэтике романа Ф. М. Достоевского «Село Степанчиково и его обитатели»"
}

Аннотация. В статье предлагается одна из возможных интерпретаций семантики заглавного топонима произведения Ф. М. Достоевского «Село Степанчиково и его обитатели», анализируется тип ойконима и его словообразовательная модель. Номинация «Село Степанчиково» вписывается в усадебный текст русской культуры и литературы. Автор связывает номинацию усадьбы Ростанева с личным провинциальным опытом писателя, главное место в котором принадлежит Семипалатинску. Доминантный аллюзивный топоним «Село Степанчиково» актуализирует внетекстовую информацию и подтекст произведения, предположительно отсылая к имени купца Степана Степанова, у которого квартировал близкий друг Достоевского А. Е. Врангель. Такие детали, как имя персонажа Степана Бахчеева, «нестерпимый зной», редкие цветы в усадьбе, слуга-казачок, отсылают к имению Степана Степанова «Казакову Саду», которое арендовал А. Е. Врангель и где друзья проводили летнее время. Автор исследования приходит к выводу, что включение сибирского биографического контекста Достоевского в интерпретацию семантики заглавия романа «Село Степанчиково и его обитатели» расширяет смысловое наполнение ойконима.

Ключевые слова: Ф. М. Достоевский, «Село Степанчиково и его обитатели», топос, усадебный текст, сибирский текст, Семипалатинск

$\mathrm{P}$ оману «Село Степанчиково и его обитатели» (1859) в творческой эволюции Ф. М. Достоевского принадлежит особое место «второго дебюта». Вместе с повестью «Дядюшкин сон» (1859) он восходит к единому замыслу комедии, а позднее комического романа, которым писатель, как в свое время «Бедными людьми», стремился возобновить литературную карьеру1

Публикация нового романа Достоевского, который в письме к брату Михаилу он называл своим «лучшим <...> произведением» $\left(28_{1}, 326\right)$, прошла незамеченной, и в литературоведении долгое время существовала инерция несерьезного 
отношения к произведению как к «самому веселому и беспечному созданию Достоевского» [Гроссман: 7], написанному автором «из обломков чужих и своих созданий», «без глубоких идей <...> без всякой претензии со стороны автора» [Кирпотин: 547]. Отношение поменялось после исследования Ю. Н. Тынянова «Достоевский и Гоголь. К теории пародии» [Тынянов], задавшего целое направление изучения текста в интертекстуальном аспекте (см., напр.: [Алексеев], [Реизов], [Туниманов], [Захаров, 1981, 1985, 2013], [Семыкина, 1992, 1997, 2008], [Лотман, 1987, 1996], [Кибальник], [Нестюричева], [Виноградов] и др.). Действительно, стремясь преодолеть вынужденный жизненный и творческий кризис и найти выход из экзистенциальной ситуации, Достоевский создает произведение, отличающееся диалогичностью и полемичностью в отношении саморефлексии и литературной традиции. Для автора было важно определить свою литературную позицию и художественную стратегию.

До конца не решен в науке и вопрос о жанре произведения, отличающегося синтетическим характером. «Село Степанчиково» ученые рассматривают как комическую повесть (см., напр.: [Кирпотин], [Туниманов], [Щенников], [Утехин] и др.), либо как выражение «нового качества прозы, предвосхищение манеры повествования будущих романов» [Захаров, 2013: 181], «экспериментальную площадку», «своеобразный “конспект”", «переходную ступень в разработке поздних романов-трагедий», «комическую антиутопию» [Семыкина, 1992: 11].

На наш взгляд, для этапа семипалатинской ссылки характерна одновременность психологических процессов выстраивания Достоевским собственной личности и поиск, осмысление и апробация опорных точек новых творческих координат. Особое внимание следует уделить деталям жизни Достоевского в провинции, что позволит точнее интерпретировать авторский замысел, раскрыть своеобразие творческой манеры, писательской стратегии и нарративной структуры текста.

В целом семантика заглавия этого провинциального романа исследователями недооценивалась. Две версии его значения предлагает С. А. Кибальник, связывая название с литературным контекстом. В монографии «Проблемы интертекстуальной 
поэтики Достоевского» он убедительно доказал, что «“Село Степанчиково” представляет собой в каком-то смысле пародию на Петрашевского и общество петрашевцев...» [Кибальник: 128]. Исследователь называет «одним из основных претекстов утопический роман Этьена Кабе “Путешествие в Икарию”, самую известную и пользовавшуюся широкой популярностью беллетристическую популяризацию идей социальных утопистов. Хорошее знакомство Достоевского с этим романом удостоверяется его известными словами о том, что “жизнь в Икарийской коммуне или фаланстере представляется ему ужаснее и противнее всякой каторги". Французское имя автора "Voyage en Icarie" - книги, которая не только входила в круг чтения петрашевцев, но и пользовалась гораздо более широкой популярностью, - “Etienne" - имеет в русском языке четкое соответствие, и это имя “Степан”. Таким образом, тот антисоциалистический подтекст <...> находит криптографическое выражение также и в заглавии повести Достоевского» [Кибальник: 88]. Кроме того, «известия о последних годах жизни и трагическом конце Кабе, которые Достоевский мог, хотя и с опозданием, извлечь из русской и иностранной печати, возможно, стали для него дополнительным внутренним импульсом к созданию повести “Село Степанчиково и его обитатели”...” [Кибальник: 148]. Исследователь также связывает название повести с гоголевской традицией, точнее с поговоркой «ни в городе Богдан, ни в селе Селифан» [Кибальник: 87]².

Подробно вопросу гоголевских традиций в романе уделил внимание И. А. Виноградов, предостерегая от прямого отождествления героя и его прототипа: «Трудно сказать, чем руководствовался Достоевский, наделяя своего персонажа чертами Гоголя. Следует, впрочем, со всей определенностью подчеркнуть, что речь в данном случае идет лишь об отдельных гоголевских чертах и высказываниях, ничуть не более; смысл и содержание образа Фомы Опискина принципиально иные» [Виноградов: 60].

Вокруг романа «Село Степанчиково» сложилась парадоксальная ситуация, когда латентные субтексты названы и описаны, а более близкие и очевидные биографические и литературные факты, ставшие непосредственным катализатором 
творческого процесса, еще не получили в науке должного внимания.

С одной стороны, Достоевскому было важно в заглавии обозначить культурную кодовость места, но с другой, - не менее значимо зашифровать, завуалировать биографический контекст, в связи с чем топоним становится референциальным знаком, знаком-ключом, разгадкой ребуса. Поэтому представляется целесообразным еще раз вернуться к вопросу номинации текста в более близком биографическом контексте сибирской жизни писателя.

По мнению С. А. Зинина, ономастика в художественных произведениях Достоевского «включает около 4400 поэтонимов в первичной номинации без учета различных фонетико-орфографических и деривационных вариантов. В этом поэтическом пространстве 79,9\% поэтонимов приходится на антропонимы, затем $28,1 \%$ составляют топонимы и только 0,1\% включают в себя другие разряды собственных имен» [Зинин]. Литературный топоним всегда создается автором намеренно, с суггестивной целью. Направленной номинативностью топонима обусловлена его активная роль в осуществлении авторского замысла, приобретении дополнительных смысловых оттенков в глубокой образной перспективе произведения. Добавим, что с точки зрения текстосимметрики, заглавие - это сильная позиция, доминанта текста. Только в двух заглавиях произведений Достоевского изначально использовались топонимы. Однако авторское название «Рулетенбург» по просьбе издателя Ф. Т. Стелловского было изменено на более понятное для русского читателя - «Игрок». Таким образом, «Село Степанчиково и его обитатели» является единственным текстом, в заглавии которого использован топоним.

И. Л. Волгин ошибочно полагает, что «"Село Степанчиково” - единственное произведение Достоевского, действие которого разворачивается в помещичьей усадьбе» [Волгин: 8-9]. На самом деле, в усадьбе действие происходит и в повести «Маленький герой», усадебные предыстории есть в романах «Униженные и оскорбленные» и «Идиот». Значимо, что писатель именно в кризисный период заключения и ссылки создает 
произведения с усадебным хронотопом, а также с парадизными топосами или их развенчанием.

Традиция усадебной повести и романа сформировалась до Достоевского, русская литература XIX в. «осмысляла помещичью усадьбу в категориях идиллии» [Дмитриева, Купцова: 96]. Для этих произведений характерны поэтизация семейной гармонии на лоне природы, сентиментальность отношений, возвышенные чувства, культ просвещения, поклонение изящному. Подобная усадебная идиллия представлена в повестях Н. М. Карамзина «Юлия» (1796), «Рыцарь нашего времени» (1803), позднее в «Повестях Белкина» (1831), «Дубровском» (1833), «Евгении Онегине» (1823-1832) А. С. Пушкина, в рассказе «Дом в деревне» (1855) Я. П. Полонского.

В усадебном тексте русской литературы середины XIX в. эстетизировался быт, традиции, музыка, пение, занятие наукой, задушевные разговоры, семейное чтение, а жизнь описывалась как праздник. Однако в 1830-е гг. ситуация меняется: «...счастливые усадебные романы уходят из литературы <...>. Уже у Тургенева усадебная любовь оказывается обреченной на трагический исход; это связано и с переосмыслением статуса гостя, который теперь уже воспринимается как чужак, роковым образом вторгающийся в устоявшуюся жизнь» [Дмитриева, Купцова: 324-325].

В разработке усадебной темы Достоевский, вероятно, опирался не на творчество А. С. Пушкина и Я. П. Полонского, а на ближайший литературный контекст - И. А. Гончарова и И. С. Тургенева ${ }^{3}$. Отметим, что публикация романа «Обломов» состоялась в журнале «Отечественные записки» в первых четырех номерах за 1859 г., а «Дворянское гнездо» было опубликовано в январском номере «Современника» того же года. Роман Достоевского был отослан в редакцию журнала «Отечественные записки» в апреле-мае 1859 г., а опубликован в № 11.

С небольшими оговорками к усадебному тексту можно отнести и рассказ Тургенева «Бретёр» (1846) и пьесу «Месяц в деревне» (1855). Эпистолярий Достоевского свидетельствует, что новый роман создавался именно с оглядкой на творчество Тургенева, за которым он признавал огромный талант и считал наиболее яркой и достойной фигурой современной литературы. 
В письме А. Н. Майкову от 18 января 1856 г. Достоевский делился: «Тургенев мне нравится наиболее» $\left(28_{1}, 209\right)$. Жалуясь на необходимость писать на заказ, он сравнивал себя именно с автором романа «Дворянское гнездо». В письме от 9 мая 1859 г. брату Михаилу из Семипалатинска находим: «Я очень хорошо знаю, что я пишу хуже Тургенева, но ведь не слишком же хуже, и наконец, я надеюсь написать совсем не хуже. За что же я-то, с моими нуждами, беру только 100 руб., а Тургенев, у которого 2000 душ, по 400? От бедности я принужден торопиться, а писать для денег, следовательно, непременно портить» $\left(28_{1}, 325\right)$. О внутренней полемической соотнесенности с романом Тургенева позволяет говорить и следующее признание, в котором Достоевский сравнивает свое произведение с ближайшим литературным контекстом: «Я не хочу сказать, что я высказался в нем весь; это будет вздор! Еще будет много что высказать. К тому же в романе мало сердечного (то есть страстного элемента, как например в “Дворянском гнезде")...» $\left(28_{1}, 326\right)$.

Однако только на первый взгляд роман отвечает формальным признакам произведения с усадебным сюжетом. В середине XIX в. начался процесс разрушения усадебной культуры и в художественных текстах усилились элегические, ностальгические и даже трагические ноты. Среди обширного круга литературных претекстов романа «Село Степанчиково» неназванной осталась повесть Тургенева «Затишье» (1854), с опорой на которую, как нам представляется, и рождался замысел Достоевского. Формально она относится к жанру усадебной повести, но писатель трансформирует традицию, резко меняя финал, показывая, как за внешним благополучием усадебной жизни в Ипатовке на лоне природы скрываются сильные страсти, гибельные для оставленной любовником героини (Марья Павловна заканчивает жизнь самоубийством). Тургенев в повести иронизирует над уровнем культуры местного дворянства (особенно осмеяно незнание французского языка), развенчивает провинциальное «отупение», слухи, глушь, которую хозяин усадьбы Ипатов гордо заменяет эвфемизмом «затишье». В этом произведении Тургенев уже не поэтизирует, а критикует сложившиеся в литературе штампы 
усадебной традиции. Достоевский продолжил эту тенденцию. Автор взял форму усадебного романа, но при сохранении внешних элементов, наполнил ее другим, прямо противоположным содержанием - текст получил иронические и саркастические тона. Его структура гораздо сложнее, а проблематика глубже. Идиллический топос романа постоянно сатирически переворачивается, иронически снижаются мотивы искушения, грехопадения, искупления, нарративы проповеди и смирения.

Героями усадебного романа в ее традиционном варианте являются полковник Ростанев, его возлюбленная Настенька, племянник Сережа, дети Илюша и Саша. За счет введения новых, нехарактерных для усадебной прозы героев, таких как Опискин, Мизинчиков, Обноскин, Крахоткины, Татьяна Ивановна, и связанных с ними сплетен, интриг, скандалов, похищений, формируются черты новой романной манеры. С другой стороны, обязательные в усадебной повести трагический финал и воспоминания об ушедшей молодости и несостоявшемся счастье у Достоевского заменены благополучным финалом обретения «возращенного рая» и созданием семейной идиллии. В то же время начатая Пушкиным и развитая Тургеневым тенденция пародирования жанра усадебной повести или романа Достоевским продолжена.

Вопрос о значении литературного топонима необходимо рассматривать с учетом его восприятия на определенном фоне, которым является прежде всего реальная ойконимия. Ойконимы - названия населенных пунктов как разновидности топонимов.

Если обратиться к типичным названиям русской усадебной культуры середины XIX в., то, по нашему мнению, словообразовательные модели в названиях усадеб и дач могут быть подразделены на следующие виды:

1) с семами рая, изобилия, веселья, благоденствия: РайСеменовское, Райки, Раек, Беспечное, Беззаботы, Отрада (Богом Данная), Отрадное, Кораллово, Нескучное, Милет (сращение от «Милое лето»), Даровое, Приятная Долина, Ясная Поляна, Раздолье, Благодатная; 
2) с семами любви, надежды, братства: Люблино, Надеждино, Братиево;

3) образованные от христианских праздников или святых: Покровское, Рождествено, Троицкое, Тихвино-Никольское, Заветное;

4) образованные от имени или фамилии: Алексияновка, Ворониово, Семеновское, Куракино, Суханово;

5) образованные от названия рядом расположенного населенного пункта: Николо-Урюпино ${ }^{4}$.

Вероятно, что Достоевский использует четвертую или пятую словообразовательную модель от названия имени / фамилии владельца или населенного пункта, расположенного поблизости. Последняя ономастическая словообразовательная модель была продуктивной в отношении крестьянских хозяйств. Для названия усадеб в середине XIX в. она была нечастотной․․ Владельцы имений предпочитали их называть «“эдемными”, “парадизными”, “аркадийными” именами. Во множестве появлялись “сколки Эдема", райские уголки» с красивыми, романтически-поэтическими названиями типа Малиновка, Отрадное, Люблино и др. [Дмитриева, Купцова: 332]. Подменяя название усадьбы названием села, Достоевский иронизирует и над усадебной культурой, и над традицией усадебной прозы в литературе.

Отметим, что в середине XIX в. на территории Российской империи существовало несколько сел с названием Степанчиково. Одно из них в Борисоглебском уезде Ярославской губернии. Об этом документально свидетельствуют архивные документы, связанные с церковью Рождества Божией Матери $(1789 \text { г. })^{6}$. Также существовали сельцо Степанчиково во Владимирской губернии Александровского уезда («Свод законов Российской Империи») и сельцо Степанчиково в Ижевском стану («Писцовые книги», XVI в.) ${ }^{7}$. Старинная вотчина Степанчиково была записана за одним из предков великого русского поэта - думным дворянином Гаврилой Григорьевичем Пушкиным [Веселовский: 189].

Неизвестно, знал ли об их существовании $Ф$. М. Достоевский. Нас интересует не столько проблема локальной идентификации, сколько проблема осмысления художественной стратегии 
писателя, которая не может быть понята без латентной семантики заглавного топонима, формирующего ономастический фон произведения в целом.

В трех километрах от усадьбы Достоевских Даровое располагалось имение Иванчиково, которое было хорошо известно будущему писателю (ныне - это населенный пункт в Зарайском районе Московской области) ${ }^{8}$. Ойконим Степанчиково образован по такой же словообразовательной ономастической модели. Использование уменьшительно-ласкательного суффикса -чик указывает на небольшой, мелкопоместный характер имения, а также вносит игровой аспект, соотносясь с карнавальным характером происходящих в имении событий. «Село Степанчиково» открывается представлением главного героя, полковника, который, выйдя в отставку, зажил в имении «как будто всю жизнь свою был коренным, не выезжавшим из своих владений помещиком» $(3,5)$.

С лингвистической точки зрения словообразование ойконима шло в направлении от антропонима следующим образом: Степан - Степанчиково с использованием уменьшительноласкательного суффикса -чик и топонимообразующих формантов -ов и -о, участвующих в словообразовательном процессе вместе в одном деривационном этапе, образуя морфемный комплекс -ово 9 . Подобную словообразовательную модель ойконима, образованного от имени владельца земельного участка или надела, отмечает И. А. Воробьева: «...деревни возникали на базе <..> заимок и сохраняли имя, прозвище первого основателя» [Воробьева: 35].

Вероятно, Достоевский с помощью словообразовательных формантов стремился оживить внутреннюю форму ойконима, актуализируя в нем и уменьшительный, и игровой характер одновременно. Кроме того, использование уменьшительноласкательных суффиксов характерно для разговорной речи, а именно - для просторечия-2 (по терминологии Л. П. Крысина ${ }^{10}$ ).

Обилие формантов с уменьшительным значением придает тексту особую стилистическую окрашенность. Кроме того, один из второстепенных героев романа, который стремится к выгодной женитьбе, имеет говорящую фамилию - Мизинчиков ${ }^{11}$. Частое использование автором слов с уменьшительно- 
ласкательным суффиксом -чик действительно может быть выражением стремления Достоевского путем игрового отношения в разных диапазонах (вектор изменялся от осторожного пародирования до саркастического снижения) выйти из ситуации жизненного и творческого кризиса.

Итак, попытаемся ответить, по какой причине в качестве доминантного аллюзивного топонима была избрана номинация «Село Степанчиково»? Можно предположить, что на процесс номинации могло повлиять ближайшее семипалатинское окружение писателя. Прежде всего, это хорошо знакомый Достоевскому купец Федор Степанович Степанов. Информация о нем содержится в статье Н. И. Левченко «Круг семипалатинских знакомых Достоевского», где автор отмечает, что «у него квартировал А. Е. Врангель», близкий друг писателя. Также исследовательница пишет о том, что «Достоевский давал уроки математики 12-летней племяннице купца Марине. Да, вероятно, Достоевскому было и просто приятно встречаться с этим человеком. Отец его, русский купец Cmепан Cmепанов, много сделал для налаживания торговых отношений России и Востока, мать - казашка. Он закончил томскую гимназию с отличием, считался одним из образованных купцов Семипалатинска. С 1854 г. Степанов 16 лет был почетным блюстителем семипалатинских училищ. Ежегодно на нужды учебных заведений он выделял 300 рублей серебром, на его средства ежегодно проводился ремонт учебных зданий, а в 1858 г. он выделил деньги на строительство нового каменного здания училища. Благодаря его стараниям в семипалатинских училищах были лучшие библиотеки среди всех учебных заведений Томской губернии» (курсив мой. E. С.) [Левченко: 245].

Барон А. Е. Врангель в своих «Воспоминаниях» пишет о Степанове как о радушном, предупредительном хозяине: «Хозяинъ мой, полукиргизъ, купецъ Степановъ, добрый, услужливый, привътливый, - дЂлалъ все возможное, чтобы быть мнъ и пріятнымъ и полезнымъ» ${ }^{12}$. Такая характеристика перекликается с образом Ростанева из романа «Село Степанчиково»: 
«Трудно было себе представить человека смирнее и на все согласнее. Если $б$ его вздумали попросить посерьезнее довезти кого-нибудь версты две на своих плечах, то он бы, может быть, и довез; он был так добр, что в иной раз готов был решительно все отдать по первому спросу и поделиться чуть не последней рубашкой с первым желающим» $(3,5)$.

Возможно ли найти параллели семипалатинских впечатлений в художественном тексте? Есть ли в романе герой по имени Степан? Такой герой появляется почти сразу, во второй главе. Это Степан Алексеевич Бахчеев. Так, имя второстепенного персонажа корреспондирует с названием села и усадьбы, придавая им особую значимость ${ }^{13}$. Фамилия героя, без сомнения, восходит к слову бахча и является семипалатинским знаком. Как писал в мемуарах А. Е. Врангель, «я жиль на самомъ берегу Иртыша <...> неподалеку былъ островъ съ огородами и бахчами дынь и арбузовъ. <..> Арбузы и дыни стали появляться только съ первыми поселенцами изъ Малороссіи, которые въ началь 50-хъ годовъ стали селиться по рбкъ Лепсъ и на Копаль» (курсив мой. - E. C.) ${ }^{14}$.

В. Н. Захаров предлагает иное толкование семантики имени героя: «У Достоевского, как правило, имя представляет героя, создает его образ. <...> Степан Алексеевич Бахчеев <..> это имя как бы рекомендует его - степной помещик, сопрягая внешнее совпадение (Степан - степь) и внутреннее значение слов (бахча - Бахчеев)» [Захаров, 1981: 208]. Действительно, степь была доминантным впечатлением от Семипалатинска, как справедливо указывает ученый. Так, в письме брату Михаилу от 27 марта 1854 г. Достоевский отмечал: «Здесь уже начало киргизской степи. Город довольно большой и людный. $<\ldots>$ Степь открытая. <...> Растительности решительно никакой, ни деревца - чистая степь» $\left(28_{1}, 178-179\right)$.

Добавим, что именно в главе, названной «Господин Бахчеев», содержится упоминание «нестерпимого зноя» $(3,20)$, которое может быть расценено как еще один семипалатинский знак. О жарком лете Достоевский сообщал брату в том же письме (от 27 марта 1854 г.): «Лето длинное и горячее» $\left(28_{1}, 179\right)$, об этом писал и А. Е. Врангель: «Лътомъ Семипалатинскъ невыносимъ: страшно душно», «Дни стояли ужъ очень жаркіе» ${ }^{15}$. 
Важно указать, что непосредственные семипалатинские впечатления и литературная традиция усадебного текста в творческом процессе Достоевского соединяются с его личным детским опытом жизни в усадьбе. Так, А. Е. Врангель особенно акцентирует воспоминания детства писателя об отеческом имении Даровом с его липами: «Въ городъ на дворъ уже заблаговременно мы устроили парники и подготовили разсаду. Достоевскаго это чрезвычайно радовало и занимало и не разъ вспоминалъ онъ свое дътство и родную усадьбу. Въ началь апрьля мы съ Ө. М. переьхали въ наше Эльдорадо, въ “Казаковъ Садъ”. <.. .> передъ домомъ устроили мы цвътники. Одна большая аллея проръзала весь садъ съ старыми деревьями» ${ }^{16}$. В романе Достоевского цветники и цветы выступают как обязательный атрибут гармоничной усадебной жизни: «Пройдя аллею столетних лип, я ступил на террасу, с которой стеклянною дверью прямо входили во внутренние комнаты. Эта терраса была окружена клумбами цветов и заставлена горшками дорогих растений» $(3,31)^{17}$; в комнате Фомы Фомича Опискина «горшки с цветами стояли на окнах и на мраморных круглых столиках перед окнами» $(3,130)$. Цветочному раю «Казакова Сада» в мемуарах Врангеля посвящен следующий фрагмент: «Время въ “Казаковомъ Саду” шло довольно быстро и пріятно. Къ намъ то и дъло наъзжали знакомые и завидовали нашему благоустройству <...>. Стояли чудные майскіе дни, зацвъли мои цвътники, - чудесныя георгины, гвоздики, левкои и проч. благодаря тучной нетронутой почвъ вышли на славу намъ...» ${ }^{18}$.

Помимо цветников, летняя дача друзей имела небольшое хозяйство: «Мы устроились совсьмъ по-помбщичьи. Я завелъ куръ, трехъ маленькихъ поросятъ отъ дикихъ кабановъ и, ради потьхи, даже ручного, какъ собака, волченка» ${ }^{19}$. Пусть в игровом, уменьшенном варианте, но друзья воссоздают усадебную атмосферу, соблюдая неписанный регламент всего необходимого: «При домъ были конюшни, сараи и обширный дворъ. Все это обнесено высокимъ досчатымъ заборомъ, а весь садъ и огородъ высокимъ частоколомъ. Усадьба наша расположена была на высокомъ правомъ берегу Иртыша, къ рбкъ шелъ отлогій зеленый лугъ» ${ }^{20}$. 
Кроме того, Врангель вспоминает об импровизированном театре, устроенном в манеже Семипалатинска, который неожиданно завершился громким скандалом: «Разъ, помню, писаря батальона устроили въ манежь представленіе, играли какую-то пьесу. Достоевскій помогалъ имъ совътами, повелъ и меня смотрбть. Кажется, весь городъ собрался, особенно любопытный прекрасный полъ; манежъ былъ набитъ... И кончилось это удовольствіе скандаломъ. Въ антрактъ, въ видъ дивертисмента, вышли солисты-писаря и, думая позабавить публику, запъли такія сальныя пъсни, преподнесли такіе срамные куплеты, что дамы бросились бъжать, а Бъликовъ и офицеры пришли въ неистовый восторгъ и буквально гоготали отъ удовольствія. Повидимому эти пъсни и куплеты были излюбленные сибирскіе, такъ какъ въ 1859 году я ихъ вновь услышалъ въ бытность мою въ Хабаровскь, на подобномъ же солдатскомъ праздникъ, и также къ вящшей радости сибирскаго бомонда $»^{21}$.

Р. Х. Якубова в статье «Балаганный текст в повести Ф. М. Достоевского “Село Степанчиково и его обитатели”» полно и убедительно описала, как народный театр является скрытым действующим лицом произведения, незримо присутствуя на разных его уровнях: словесном, персонажном, сюжетном [Якубова]. Мы обратим внимание на непристойный характер сибирских песен, которые действуют на аудиторию амбивалентно: дам заставляют в ужасе разбегаться и одновременно приводят в восторг мужчин. Может быть, в трансформированном виде этот факт в тексте романа связан с пляской Фалалея под аккомпанемент народного оркестра, состоящего из двух балалаек, гитары, скрипки и бубна. Фалалей танцует «комаринского» весело, задорно, легко и свободно, приводя в восторг своих зрителей. И только Фома Фомич преследует ребенка за неприличность содержания этой песни (см. об этом: [Якубова, 2007: 399], [Лотман, 1996: 71-73, 76]).

Таким образом, включение семипалатинского и, шире, сибирского, биографического контекста Достоевского в интерпретацию семантики заглавия романа расширяет смысловое наполнение ойконима, усиливает его символический ореол, раздвигая границы ономастического пространства произведения, позволяя осмыслить семантику заглавия романа в биографическом и литературно-культурном контексте. 


\section{Примечания}

* Исследование выполнено при финансовой поддержке РФФИ и Министерства образования и науки Алтайского края в рамках научного проекта № 17-14-22003 «Сибирь Ф. М. Достоевского: семиотика пространства и нарративные стратегии».

1 См.: [Примечания] // Достоевский Ф. М. Полн. собр. соч.: в 30 т. Л.: Наука, 1972. Т. 3. С. 489. Далее ссылки на это издание приводятся в тексте статьи с указанием тома, книги (нижний индекс), страницы в круглых скобках.

2 «У Гоголя во второй главе “Мертвых душ” в характеристике Манилова упоминается село Селифан: “Есть род людей, известных под именем: люди так себе, ни то ни се, ни в городе Богдан, ни в селе Селифан” $<. .>$. Оно представляет собой составную часть старинной русской поговорки. Как известно, имя Селифан носит кучер Чичикова, а что касается выражения “ни в городе Богдан”, то есть вариант этой пословицы, в которой эта часть звучит как раз как “ни в городе Степан”. Своей бесхарактерностью Ростанев вполне мог вызвать у Достоевского подобные ассоциации, а уменьшительно-ласкательный суффикс: не Степан, а Степанчик - соответствует жанру комического романа. Прибавим, что имя “Степан” хорошо подходило для заглавия романа Достоевского, поскольку в имении Ростанева оказалась собрана самая разношерстная компания (что подчеркнуто второй частью заглавия: “...и его обитатели”), между тем греческое слово “стефанос”, от которого происходит это имя, означает “венок” [Кибальник: 87].

3 По мнению С. А. Кибальника, «топологические заглавия вообще нередко встречаются в послегоголевской литературе. Так, помимо “Дома в деревне” Я. П. Полонского, можно вспомнить напечатанные в 1859 г. в “Современнике” “Дворянское гнездо” Тургенева и даже роман Г. П. Данилевского “Село Сорокопановка”. Последнее заглавие, ставшее известным Достоевскому уже после того, как он озаглавил свою повесть “Село Степанчиково...”, демонстрирует устойчивость пушкинско-гоголевской топологической модели, которая в случае с заглавиями произведений Достоевского и Данилевского построена на анафоре, оттеняющей тождество имени и отчества главного героя “Фома Фомич”. На сходной анафоре построена также вторая часть народной пословицы, использованной Гоголем: “ни в селе Селифан”» [Кибальник: 87-88].

4 Названия усадеб почерпнуты: [Евангулова], [Дмитриева, Купцова].

5 Подробнее о традициях называния усадеб см.: [Дмитриева, Купцова: 334]. «B XVII-XVIII вв. названия усадеб часто давались по фамилиям владельцев (Воронцово, Куракино, Обольяниново и т. п.). В конце XVIII - начале XIX в. уже не только царские резиденции, дворцы, парки называются семейными именами (как, к примеру, Александрова дача), но любой помещик мог назвать именами своих близких (а также уменьшительными, домашними вариантами этих имен) принадлежащие ему деревни, что 
придавало топонимам камерный, интимный характер. Вот только некоторые из подобных примеров: Александрия (гр. А. В. Браницкой), село Анна (Ростопчиных), Марьино (кн. И. И. Барятинского), Надеждино (М. М. Кугроедова, названо в честь жены, Н. И. Аксаковой) и др.» [Дмитриева, Купцова: 334].

6 Упоминания сел с таким названием имеются в архивных делах, на которые ссылается Интернет-портал архивной службы Ярославской области: (см.: URL: http://www.yar-archives.ru/archive/search/?q=\%D1\% 81\%D1\%82\%D0\%B5\%D0\%BF\%D0\%B0\%D0\%BD\%D1\%87\%D0\%B8\%D0 \%BA\%D0\%BE\%D0\%B2\%D0\%BE\&search\%5Bfund $\% 5 \mathrm{D} \% 5$ Brename $\% 5 \mathrm{D}=$ on\&search $\% 5$ Bunit $\% 5 \mathrm{D} \% 5 \mathrm{~B}$ caption $\% 5 \mathrm{D}=$ on\&id=0).

7 См. об этом: [Греков: 194-195], [Шватченко: 179].

8 Выражаем благодарность В. А. Викторовичу, который обратил наше внимание на эту информацию.

9 В диахроническом аспекте суффикс -чик действительно имеет уменьшительно-ласкательное значение, но в современном Достоевскому языке его значение несколько стирается по двум причинам: во-первых, ойконимы, как правило, теряют эмоционально-экспрессивную окрашенность, во-вторых, значение имеет только последний аффикс -ов, который образует суффиксальным способом название топонима от имени лица, который владеет земельным участком или наделом.

10 По мнению Л. П. Крысина, «просторечие - наиболее своеобразная подсистема русского национального языка» [Крысин: 53]. «Для просторечия-2 характерно использование диминутивов типа огурчик, номерок, документики, газировочка <...> как выражение своеобразно понимаемой вежливости [Крысин: 66]. Кроме того, сдвиги в структуре и характере разговорно-литературного языка приводят к активизации «следующих тенденций: усиление диалогизации устного <...> общения; усиление личностного начала; возрождение игровой, карнавальной стихии...» [Крысин: 103].

11 Эта фамилия употребляется в тексте 74 раза, включая название 10-й главы произведения. Кроме того, автор использует и другие слова с суффиксом -чик: мальчик (11), голубчик (2), розанчик (2), чепчик (2), диванчик (2), романчик (1), кончик (1), сувенирчик (1), пальчики (1). В романе есть еще слова с формантом -чик: догадчик (1) и переписчик (1), но мы их не включили в анализ, поскольку суффикс в данном случае не имеет уменьшительного значения. Кроме того, в тексте присутствуют и другие уменьшительные суффиксы: незабудочки (1), ножки (1), узелок (1), что подтверждает наличие диминутивов, также характеризующих просторечие- 2 .

12 Врангель А. Е. Воспоминанія о Ө. М. Достоевскомъ въ Сибири. 1854-56 гг. СПб.: Тип. А. С. Суворина, 1912. 221 с.

13 Добавим, что слово усадьба встречается в произведении всего 2 раза, а слово село и его словоформы - 9, включая название; селянин - 2, сельский - 2. Степанчиково встречается 15 раз, вместе с названием. 
Имя Степан упоминается в романе 29 раз (24 вместе с отчеством Алексеевич, 5 - только имя), что косвенно подтверждает нашу гипотезу.

14 Врангель А. Е. Воспоминанія... С. 22, 50.

15 Там же. С. $42,44$.

16 Там же. С. 43.

17 Совсем не обязательно, что столетние липы были знаком биографическим: «...именно липы наиболее рекомендовались садовниками для засадки закрытых аллей, и именно они получили особое распространение в русских помещичьих усадьбах, составив свой особый топос в литературе» [Купцова, Дмитриева, 2003: 60]. Поэтому липовые аллеи были знаком-символом русской усадебной культуры и усадебного текста.

18 Врангель А. Е. Воспоминанія... С. 47.

19 Там же. С. 45.

20 Там же. С. 44.

21 Там же. С. $27-28$.

\section{Список литературы}

1. Виноградов И. А. Литературная проповедь Н. В. Гоголя: pro et contra // Проблемы исторической поэтики. - 2018. - Т. 16. — № 2. - С. 49-124 [Электронный ресурс]. - URL: http://poetica.pro/files/redaktor_ pdf/1530266349.pdf (28.05.2018). DOI 10.15393/j9.art.2018.5181

2. Волгин И. Л. Долг, равный жизни // Село Степанчиково и его обитатели. Записки из подполья. Игрок. - М.: Правда, 1986. - С. 5-32.

3. Воробьева И. А. Топонимика Западной Сибири. - Томск: Изд-во Томского университета, 1977. - 152 с.

4. Греков Б. Д. Крестьяне на Руси с древнейших времен и до XVII века: в 2-х кн. - М.: Изд-во Академии наук СССР, 1954. - Книга вторая. - 470 с.

5. Гроссман Л. П. Деревня Достоевского // Достоевский Ф. М. Село Степанчиково и его обитатели. - М., 1935. - С. 7-34.

6. Дмитриева Е. Е. Жизнь усадебного мифа. Утраченный и обретенный рай / Е. Е. Дмитриева, О. Н. Купцова. - 2-е изд. - М.: ОГИ, 2008. - 528 с.

7. Евангулова О. С. Художественная «Вселенная» русской усадьбы. - М.: Прогресс-Традиция, 2003. - 304 с.

8. Захаров В. Н. Комический шедевр Достоевского // Достоевский Ф. М. Село Степанчиково и его обитатели: из записок неизвестного. - Петрозаводск: «Карелия», 1981. - С. 206-213.

9. Захаров В. Н Система жанров Достоевского: Типология и поэтика. Л.: Изд-во ЛГУ, 1985. - 209 с.

10. Захаров В. Н. Имя автора - Достоевский. Очерк творчества. - М.: Изд-во «Индрик», 2013. - 456 с.

11. Зинин С. И. Введение в поэтическую ономастику [Электронный реcypc]. - URL: http://imja.name/poehtonimy/onomprostranstvo-proizvedeniya. shtml (28.05.2018).

12. Кибальник С. А. Проблемы интертекстуальной поэтики Достоевского. - СПб.: Петрополис, 2013. - 432 с. 
13. Кирпотин В. Я. Ф.М.Достоевский: творческий путь (1821-1859). - М.: Худож. лит., 1960. - 606 с.

14. [Крысин Л. П.] Современный русский язык: Социальная и функциональная дифференциация / отв. ред. Л. П. Крысин. - М.: Языки славянской культуры, 2003. - 568 с.

15. Левченко Н. И. Круг знакомых Ф. М. Достоевского в Семипалатинский период жизни // Достоевский: Материалы и исследования. - СПб.: Наука, 1994. - Т. 11. - С. 235-246.

16. Лотман Л. М. «Село Степанчиково» Достоевского в контексте литературы второй половины XIX века // Достоевский: Материалы и исследования. - Л.: Наука, 1987. - Т. 7. - С. 152-165.

17. Лотман Л. М. О литературном подтексте одного из эпизодов повести «Село Степанчиково и его обитатели» (Сон про белого быка) // Достоевский: Материалы и исследования. - СПб.: Наука, 1996. - Т. 12. - С. 66-77.

18. Нестюричева Н. А. Реминисцентное измерение повести Достоевского «Село Степанчиково и его обитатели» // Вестник Удмурдского университета. - 2013. - Вып. 4. - С. 25-32.

19. Реизов Б. Г. Достоевский и Диккенс // Реизов Б. Г. Из истории европейских литератур. - Л.: Изд-во Ленинградского университета, 1970. - C. 159-169.

20. Семыкина Р. С.-И. Проза Ф. М. Достоевского 1850-х годов: «Дядюшкин сон», «Село Степанчиково и его обитатели»: (Комическое: мир и характеры): автореф. дис. ... канд. филол. наук. - Екатеринбург, 1992. - 17 с.

21. Семыкина Р. С.-И. Поэтика хронотопа в повести «Село Степанчиково и его обитатели» // Культура и текст. - 1997. — № 2. - С. 14-18.

22. Семыкина Р. С.-И. Село Степанчиково и его обитатели // Достоевский: сочинения, письма, документы: словарь справочник / сост. и науч. ред. Г. К. Щенников, Б. Н. Тихомиров. - СПб., 2008. - С. 163-167.

23. Тынянов Ю. Н. Достоевский и Гоголь (к теории пародии) // Поэтика. История литературы. Кино. - М., 1977. - С. 198-226.

24. Утехин Н. П. Комические повести и рассказы Достоевского // Село Степанчикво и его обитатели. - М.: Советская Россия, 1986. - С. 3-32.

25. Шватченко О. А. Светские феодальные вотчины в России во второй половине XVII века: (историко-географический очерк). - М.: Изд. центр ИРИ РАН, 1996. - 286 с.

26. Щенников Г. К. Достоевский и русский реализм. - Свердловск: Изд-во Уральского университета, 1987. - 350 с.

27. Якубова Р. Х. Балаганный текст в повести Ф. М. Достоевского «Село Степанчиково и его обитатели» // Достоевский и современность: материалы XX Международных Старорусских чтений 2005. - Великий Новгород, 2006. - С. 410-421.

Информация об авторе: Сафронова Елена Юрвевна - кандидат филологических наук, доцент кафедры общей и прикладной филологии, литературы и русского языка Алтайского государственного университета.

Дата поступления в редакцию: 15.06 .2018 Дата публикаиии: 01.10.2018 
Elena Yu. Safronova

(Barnaul, Russian Federation)

esafr@mail.ru

\title{
Genius Loci in the Poetics of the Novel "The Village of Stepanchikovo and Its Inhabitants" by F. M. Dostoevsky
}

\begin{abstract}
The article offers one of the possible interpretations of the semantics of the title toponym of the work of F. M. Dostoevsky "The Village of Stepanchikovo and Its Inhabitants", gives the definition of an allusive toponym, analyzes the type of oikonym and its word-forming model. The naming "Stepanchikovo Village" fits into the manor text (enters in the farmstead text) of russian culture and literature. The author ties the nomination of the estate of Rostanev with the personal provincial experience of the writer, the main place in which belongs to Semipalatinsk. The dominant allusive toponym of Stepanchikovo village actualizes the non-textual information and the subtext of the work, presumably referring to the name of merchant Stepan Stepanov, who hosted A. E. Wrangel, Dostoevsky's close friend. Such details as the name of the character Stepan Bakhcheev, "intolerable heat", rare flowers in the estate and the Cossack servant allude to the estate "Kazakov's garden" belonging to Stepan Stepanov, which used to be rented by A. E. Wrangel for spending summer time with friends.
\end{abstract}

Keywords: Dostoevsky, “The Village of Stepanchikovo and Its Inhabitants", allusive toponym, topos, manor text, Siberian text, Semipalatinsk

\section{References}

1. Vinogradov I. A. The Literary Sermon of N. Gogol: Pro et Contra. In: Problemy istoricheskoy poetiki [The Problems of Historical Poetics], 2018, vol. 16, no. 2, pp. 49-124. Available at: http://poetica.pro/files/redaktor_pdf/1530266349. pdf (accessed on May 28, 2018). DOI 10.15393/j9.art.2018.5181 (In Russ.)

2. Volgin I. L. The Duty Equal to Life. In: Selo Stepanchikovo i ego obitateli. Zapiski iz podpol'ya. Igrok [The Village of Stepanchikovo and Its Inhabitants. Notes from the Underground. The Gambler]. Moscow, Pravda Publ., 1986, pp. 5-32. (In Russ.)

3. Vorob’eva I. A. Toponimika Zapadnoy Sibiri [Toponymics of Western Siberia]. Tomsk, Tomsk State University Publ., 1977. 152 p. (In Russ.)

4. Grekov B. D. Krest'yane na Rusi s drevneyshikh vremen i do XVII veka: v 2-kh knigakh [The Peasants in Russia from the Ancient Times to the 17th Century: in 2 Books]. Moscow, Academy of Sciences of the USSR Publ., 1954, book 2. 470 p. (In Russ.)

5. Grossman L. P. The Village of Dostoevsky. In: Dostoevskiy F. M. Selo Stepanchikovo i ego obitateli [Dostoevsky F. M. The Village of Stepanchikovo and Its Inhabitants]. Moscow, 1935, pp. 7-34. (In Russ.) 
6. Dmitrieva E. E. Zhizn' usadebnogo mifa. Utrachennyy i obretennyy ray [The Life of the Homestead Myth. The Lost and Regained Paradise]. Moscow, Ob"edinennoe gumanitarnoe izdatel'stvo Publ., 2008. 528 p. (In Russ.)

7. Evangulova O. S. Khudozhestvennaya «Vselennaya» russkoy usad'by [The Artistic "Universe" of the Russian Homestead]. Moscow, Progress-Traditsiya Publ., 2003. 304 p. (In Russ.)

8. Zakharov V. N. The Comic Masterpiece of Dostoevsky. In: Dostoevskiy F. M. Selo Stepanchikovo i ego obitateli: iz zapisok neizvestnogo [Dostoevsky F. M. The Village of Stepanchikovo and Its Inhabitants: from the Notes of the Unknown]. Petrozavodsk, Kareliya Publ., 1981, pp. 206-213. (In Russ.)

9. Zakharov V. N. Sistema zhanrov Dostoevskogo: tipologiya i poetika [The System of Genres of Dostoevsky: Typology and Poetics]. Leningrad, Pushkin Leningrad State University Publ., 1985. 209 p. (In Russ.)

10. Zakharov V. N. Imya avtora - Dostoevskiy. Ocherk tvorchestva [The Author's Name Is Dostoevsky. An Essay on the Creative Work]. Moscow, Indrik Publ., 2013. 456 p. (In Russ.)

11. Zinin S. I. Vvedenie v poeticheskuyu onomastiku [Introduction to the Poetic Onomastics]. Available at: http://imja.name/poehtonimy/onomprostranstvoproizvedeniya.shtml (accessed on May 28, 2018). (In Russ.)

12. Kibal'nik S. A. Problemy intertekstual'noy poetiki Dostoevskogo [Problems of the Intertextual Poetics of Dostoevsky]. St. Petersburg, Petropolis Publ., 2013. 432 p. (In Russ.)

13. Kirpotin V. Ya. F. M. Dostoevskiy: tvorcheskiy put'(1821-1859) [F. M. Dostoevsky: Creative Way (1821-1859)]. Moscow, Khudozhestvennaya literatura Publ., 1960. 606 p. (In Russ.)

14. Krysin L. P. Sovremennyy russkiy yazyk: Sotsial'naya i funktsional'naya differentsiatsiya [Modern Russian Language: Social and Functional Differentiation]. Moscow, Yazyki slavyanskoy kul'tury Publ., 2003. 568 p. (In Russ.)

15. Levchenko N. I. The Circle of Friends of F. M. Dostoevsky in the Semipalatinsk Period of Life. In: Dostoevskiy: Materialy i issledovaniya [Dostoevsky: Materials and Researches]. St. Petersburg, Nauka Publ., 1994, vol. 11, pp. 235-246. (In Russ.)

16. Lotman L. M. "The Village of Stepanchikovo" by Dostoevsky in the Context of Literature of the Second Half of the 19th Century. In: Dostoevskiy: Materialy $i$ issledovaniya [Dostoevsky: Materials and Researches]. Leningrad, Nauka Publ., 1987, vol. 7, pp. 152-165. (In Russ.)

17. Lotman L. M. On the Literary Subtext of One of the Episodes of the Novel "The Village of Stepanchikovo and Its Inhabitants" (A Dream About a White Bull). In: Dostoevskiy: Materialy $i$ issledovaniya [Dostoevsky: Materials and Researches]. St. Petersburg, Nauka Publ., 1996, vol. 12, pp. 66-77. (In Russ.)

18. Nestyuricheva N. A. Reminiscence Dimension of Dostoevsky's Novel “The Village of Stepanchikovo and Its Inhabitants". In: Vestnik Udmurdskogo universiteta [Bulletin of Udmurt University], 2013, issue 4, pp. 25-32. (In Russ.)

19. Reizov B. G. Dostoevsky and Dickens. In: Iz istorii evropeyskikh literatur [From the History of European Literatures]. Leningrad, Pushkin Leningrad State University Publ., 1970, pp. 159-169. (In Russ.) 
20. Semykina R. S.-I. Proza F. M. Dostoevskogo 1850-kh godov: «Dyadyushkin son», «Selo Stepanchikovo i ego obitateli»: (Komicheskoe: mir i kharaktery): avtoref. dis. ... kand. filol. nauk [The Prose of F. M. Dostoevsky of the 1850s: "Uncle's Dream", "The Village of Stepanchikovo and Its Inhabitants": (The Comic: the World and Characters). PhD. philol. sci. diss. abstract]. Yekaterinburg, 1992. 17 p. (In Russ.)

21. Semykina R. S.-I. The Poetics of the Chronotope in the Novel "The Village of Stepanchikovo and Its Inhabitants". In: Kul'tura i tekst [Culture and Text], 1997, no. 2, pp. 14-18. (In Russ.)

22. Semykina R. S.-I. The Village of Stepanchikovo and Its Inhabitants. In: Dostoevskiy: sochineniya, pis'ma, dokumenty: slovar' spravochnik [Dostoevsky: Works, Letters, Documents: Word Reference]. St. Petersburg, 2008, pp. 163-167. (In Russ.)

23. Tynyanov Yu. N. Dostoevsky and Gogol (More on the Theory of Parody). In: Poetika. Istoriya literatury. Kino [Poetics. History of Literature. Cinema]. Moscow, 1977, pp. 198-226. (In Russ.)

24. Utekhin N. P. Comic Novels and Stories by Dostoevsky. In: Selo Stepanchikovo $i$ ego obitateli [The Village of Stepanchikovo and Its Inhabitants]. Moscow, Sovetskaya Rossiya Publ., 1986, pp. 3-32. (In Russ.)

25. Shvatchenko O. A. Svetskie feodal'nye votchiny v Rossii vo vtoroy polovine XVII veka: (istoriko-geograficheskiy ocherk) [The Secular Feudal Homesteads in Russia in the Second Half of the 17th Century: (Historical and Geographical Essay)]. Moscow, Institute of Russian History of the Russian Academy of Sciences Publ., 1996. 286 p. (In Russ.)

26. Shchennikov G. K. Dostoevskiy i russkiy realizm [Dostoevsky and Russian Realism]. Sverdlovsk, A. M. Gorky Ural State University Publ., 1987. 350 p. (In Russ.)

27. Yakubova R. Kh. The Farcical Text in the Novel by F. M. Dostoevsky "The Village of Stepanchikovo and Its Inhabitants". In: Dostoevskiy i sovremennost' [Dostoevsky and Modern Age]. Novgorod the Great, 2006, pp. 410-421. (In Russ.)

Information about the author: Safronova Elena Yu. - PhD in Philology, Associate Professor of the Department of General and Applied Philology, Literature and Russian Language of Altai State University.

Received: June 15, 2018 Date of publication: October 1, 2018 